\title{
PENGARUH KARAKTERISTIK IBU DAN DUKUNGAN SUAMI TERHADAP PEMERIKSAAN KEHAMILAN DI KECAMATAN ANGKOLA TIMUR KABUPATEN TAPANULI SELATAN
}

\author{
Rosmawaty Harahap ${ }^{1}$, Meidiawaty Siregar ${ }^{2}$ \\ ${ }^{1}$ Dosen Prodi Kebidanan Padangsidempuan, Poltekkes Medan \\ ${ }^{2}$ Dosen Prodi Kebidanan Padangsidimpuan, Poltekkes Medan
}

\begin{abstract}
One of the efforts to observe the progress of pregnancy in order to ascertain good health of the mother and the womb is by getting antenatal care. The result of the preliminary survey in working area of Health Centre Pargarutan, East Angkola district showed that according to the data 2009, the coverage of K4 was 73,5\% and the data 2010, the coverage of K4 was only 78\% (it is still far from the expected coverage by Ministry of Health, that 90\%). This research was aimed to analyze the influence of the characteristics of the mother (parity, age, occupation, education) and husband's support (informational, assessment, instrumental and emotional) on antenatal care. The type of the research was cross-sectional study. The research was carried out in Health Centre Pargarutan, East Angkola district. The population in this research were all pregnant women in Health Centre Pargarutan, East Angkola district with KIA book. The amount of the sample were 74 pregnant women with proportional sampling technique. Data analysis used multiple logistic regression test with significance level of $95 \%(\alpha<0,05)$. The result of the research showed that there were influences of parity, emotional support and instrumental support on antenatal care. There was no influence of mother's age, education, occupation, informational support and assessment/appreciation support on antenatal care. The most dominant variable influenced on antenatal care was emotional support. It is recommended that the policy-maker should conduct cooperation in order to improve the routine socialization and counseling on the antenatal care with involve the pregnant mother's husbands to accompany them.
\end{abstract}

Keywords : Husband Support, Antenatal Care

\section{PENDAHULUAN}

Indikator keberhasilan pembangunan kesehatan dapat dilihat dari peningkatan atau penurunan derajat kesehatan. Salah satu indikator derajat kesehatan tersebut adalah Angka Kematian Ibu (AKI). Persoalan kematian yang terjadi disebabkan oleh pendarahan, eklamsi, aborsi, dan infeksi. Selain masalah medis, tingginya kematian ibu juga karena pemberdayaan perempuan yang kurang baik, latar belakang pendidikan perempuan, masalah ketidaksetaraan gender, nilai budaya, perekonomian serta rendahnya perhatian laki-laki terhadap ibu hamil dan melahirkan. Oleh karena itu, pandangan yang menganggap kehamilan adalah peristiwa alamiah perlu diubah secara sosiokultural. Sangat diperlukan upaya peningkatan pelayanan perawatan ibu hamil baik oleh pemerintah, swasta, maupun masyarakat terutama suami.

Negara-negara di dunia memberi perhatian yang cukup besar terhadap Angka Kematian Ibu (AKI), sehingga menempatkannya di antara delapan tujuan yang dituangkan dalam Millenium Development Goals (MDGs), yang harus dicapai sebelum 2015. Komitmen yang ditandatangani 189 negara pada September 2000, pada prinsipnya bertujuan untuk meningkatkan taraf hidup dan kesejahteraan manusia (Yustina, 2007).

Menurut Profil kesehatan Indonesia (2010), AKI di Indonesia menunjukkan penurunan dari tahun 1994 yaitu 394/ 100.000 Kelahiran Hidup (KH) sampai dengan 2007 yaitu 228/ $100.000 \mathrm{KH}$, dapat dilihat pada grafik dibawah ini.

Walaupun sudah terjadi penurunan AKI di Indonesia, namun angka tersebut masih menempatkan Indonesia pada peringkat 12 dari 18 negara ASEAN dan SEARO (South East Asia Region, yaitu: Bangladesh, Bhutan, Korea Utara, India, Maladewa, Myanmar, Nepal, Timor Leste, dan lain-lain ).

Di Provinsi Sumatera Utara AKI juga masih tinggi pada tahun 2009 yaitu 238/100.000 kelahiran hidup. Kabupaten Tapanili Selatan menyumbang 10 kematian ibu dari angka kematian ibu tersebut. Penyebab kematian masih disebabkan oleh trias klasik (perdarahan, infeksi dan eklamsi), dan non medis (faktor ekonomi, sosial budaya) yaitu dari masyarakat. (Profil Dinkes Prov Tapanuli Selatan, 2009).

Menurut YPKP (Yayasan Pendidikan Kesehatan Perempuan) (2006), ada dua penyebab kematian ibu yaitu penyebab langsung dan penyebab 
tidak langsung. Penyebab langsung mempunyai persentase terbesar di seluruh dunia mencapai 70\%, sedangkan di negara berkembang berkisar 95\%. Di Indonesia lebih dari 90\% kematian ibu disebabkan oleh penyebab langsung (perdarahan, infeksi dan eklamsi); persalinan lama (lebih dari 12 jam); dan aborsi tidak aman. Perdarahan merupakan penyebab terbesar terjadinya kematian ibu di seluruh dunia (25\%), infeksi/ sepsis (15\%), aborsi tidak aman (13\%), eklamsi (12\%) dan persalinan obstruksi (8\%).

Selanjutnya menurut Roeshadi (2006), di Indonesia kematian maternal sering kali berkaitan dengan faktor keterlambatan yaitu: terlambat memutuskan untuk mencari pelayanan, terlambat mencapai fasilitas kesehatan, dan terlambat menerima pelayanan yang adekuat. Pada terlambat pertama dan kedua, yang sering kali juga sebagai faktor terbanyak, peran pengambil keputusan menjadi penting baik keputusan kapan harus mendapat pertolongan atau keputusan dalam memilih tenaga penolong.

Upaya untuk mempercepat penurunan AKI telah dimulai sejak akhir tahun 1980-an melalui program Safe Motherhood Initiative yang mendapat perhatian besar dan dukungan dari berbagai pihak baik dalam maupun luar negeri. Pada akhir tahun 1990-an secara konseptual telah diperkenalkan lagi upaya untuk menajamkan strategi dan intervensi dalam menurunkan AKI melalui Making Pregnancy Safer (MPS) yang dicanangkan oleh pemerintah pada tahun 2000. Strategi MPS memfokuskan pada 3 pesan yaitu: akses terhadap pelayanan oleh tenaga terampil, akses terhadap pelayanan rujukan jika terjadi komplikasi dan pencegahan kehamilan yang tidak diinginkan dan penanganan komplikasi terhadap keguguran (Dinkes, 2007).

Pesan pertama yaitu akses terhadap pelayanan oleh tenaga terampil, diharapkan semua ibu hamil dan bersalin ditolong oleh tenaga kesehatan. Pelayanan kesehatan pada ibu-ibu hamil meliputi pelayanan antenatal di semua fasilitas pelayanan dengan mutu sesuai standar. Pesan kedua setiap komplikasi obstetri dan neonatal mendapat pelayanan yang adekuat, sehingga setiap ibu hamil harus berada sedekat mungkin pada sarana pelayanan yang mampu PONED (Pelayanan Obstetri dan Neonatal Emergensi Dasar).

Salah satu usaha yang dapat dilakukan untuk memantau kemajuan kehamilan sehingga dapat dipastikan kesehatan ibu dan janin, maka perlu dilakukan pemeriksaan kehamilan (antenatal care). Pemeriksaan kehamilan minimal 4 kali selama kehamilan dapat diketahui secara dini adanya kelainan atau komplikasi yang menyertai kehamilan, sehingga penanganan dapat dilakukan dengan tepat dan mencegah kematian ibu dan janin (Saifuddin, 2002).

Kenyataan yang terjadi para ibu hamil tidak melakukan pemeriksaan kehamilan. Banyak faktor yang menyebabkan ibu tidak memeriksakan kehamilannya. Berdasarkan penelitian yang dilakukan National Center for Women and Children's Health, Chinese Center for Disease Control and Prevention yang berjudul Analisis status program pemeriksaan antenatal di Cina tahun 2005 didapatkan hasil bahwa faktor-faktor yang memengaruhi pemeriksaan kehamilan yaitu: usia, pendidikan, kebangsaan dan sosial ekonomi. Wanita dengan buta huruf memiliki tingkat pemeriksaan kehamilan yang lebih rendah dari pada yang tidak buta huruf (Cui dkk 2005).

Simkhada dkk (2008), berpendapat bahwa faktorfaktor yang memengaruhi wanita dalam melakukan pemeriksaan kehamilan adalah: pendidikan ibu, pendidikan suami, status perkawinan, ketersediaan sarana kesehatan, biaya, pendapatan rumah tangga, pekerjaan perempuan, paparan media dan memiliki riwayat komplikasi obstetri. Kepercayaan budaya dan ide-ide tentang kehamilan juga memiliki pengaruh pada penggunaan pelayanan antenatal. Paritas memiliki efek negatif secara statistik signifikan terhadap kehadiran memadai. Perempuan paritas lebih tinggi cenderung kurang menggunakan pelayanan antenatal, ada hubungan usia perempuan dengan kunjungan antenatal.

AKI di Indonesia sesungguhnya bisa dicegah jika dilakukan perbaikan terhadap akses pelayanan kesehatan bagi ibu. Akses ibu hamil ke tempat pelayanan kesehatan juga dipengaruhi dengan adanya dukungan suami serta peran keluarga untuk membawanya ke pelayanan kesehatan disaat timbulnya masalah dalam kehamilan (Muslihatun, Mufdillah, Setiyawati, 2009).

Dukungan suami merupakan bentuk peran serta suami dan hubungan baik yang memberi kontribusi penting bagi kesehatan. Adanya kehadiran orang terdekat dapat mempengaruhi emosional atau efek perilaku bagi ibu dalam menerima kehamilan serta akses terhadap pelayanan kesehatan (Salmah dkk, 2007)

Laki-laki sebagai suami ikut berperan dalam kehidupan dan kesehatan isterinya. Suami memainkan peran kunci selama masa kehamilan dan persalinan serta setelah bayi lahir. Keputusan dan tindakan mereka berpengaruh terhadap kesakitan dan kesehatan, kehidupan dan kematian ibu dan bayinya. Suami seharusnya menemani istrinya konsultasi sehingga suami juga dapat belajar mengenai gejala dan tandatanda komplikasi kehamilan, gizi yang baik dan istirahat yang cukup bagi ibu selama masa kehamilan (Lucianawaty, 2008).

Menurut Swasono (1998), sebagian besar masyarakat masih menganut pandangan bahwa kematian pada saat kehamilan dan persalinan adalah hal yang normal dan tidak dapat dihindari, bahkan kematiannya dianggap mati syahid yang membuat ibu akan masuk surga. Bahkan dianggap kodrat yang sudah seharusnya ditanggung oleh perempuan itu sendiri. Hal ini yang mengakibatkan kurangnya penanganan dan dukungan dari suami. Mulyadin (2008), mengatakan bahwa anggapan tersebut juga dianut oleh sebagian besar masyarakat Tapanuli Selatan.

Bentuk kepedulian dan keterlibatan suami dalam menjaga kehamilan isterinya itu dimanifestasikan dalam tindakan-tindakan seperti memerhatikan gizi/makanan ibu hamil, memeriksakan kehamilan sejak dini, menjaga kesehatan fisik dan mental ibu, berdoa kepada Tuhan, mengusahakan agar 
persalinan ditolong oleh tenaga kesehatan dan mengikuti tradisi (Beni, 2000).

Bentuk kepedulian suami terhadap istri sering terabaikan karena suami tidak paham apa yang harus diketahui dan apa yang harus dilakukan ketika istri sedang hamil. Dalam hal ini diperlukan penatalaksanaan agar suami dapat menjalankan peran mengantar istri yang sedang hamil ke kondisi sempurna sehingga tercapainya kesejahteraan ibu dan anak yang optimal.

Hasil studi pendahuluan di wilayah kerja Puskesmas Paragarutan data tahun 2009 cakupan K4 sebesar 73,5\% dan data 2010 cakupan K4 hanya 78\% (masih jauh dari data cakupan yang diharapkan oleh Departemen Kesehatan yaitu 90\%). Dari beberapa orang bidan di desa yang cakupan K4 nya masih kurang menyatakan bahwa ibu-ibu hamil tersebut tidak mau datang ke Puskesmas atau Polindes untuk memeriksakan kehamilannya.

Para ibu hamil tersebut baru akan memeriksakan kehamilan apabila kehamilannya sudah kelihatan dan biasanya pada usia kehamilan sudah memasuki trimester II (4-6 bulan), dan selama ini yang dilakukan bidan di desa adalah melakukan home visit (kunjungan rumah) untuk melakukan pemeriksaan kehamilan dan dilakukan apabila bidan mengetahui ibu tersebut hamil. Di wilayah kerja Puskesmas Paragarutan sebagian besar pekerjaan para suami adalah petani. Petani tidak setiap hari harus ke sawah, ada waktu luang yang bisa digunakan untuk mengantar istri periksa hamil. Sebagian besar dari ibu hamil yang diperiksa di puskesmas dan polindes hanya datang sendiri tanpa ditemani oleh suami atau anggota keluarga lainnya. Dengan menemani istri setiap kali periksakan hamil, suami mendapatkan informasi yang sangat penting bagi kehamilan, sehingga suami dapat memberikan dukungan kepada istri yang sedang hamil, yang pada kenyataannya tidak dilakukan oleh sebagian besar para suami di wilayah kerja Puskesmas Pargarutan.

Dari fenomena tersebut terlihat bahwa ada masalah yang memengaruhi ibu hamil tidak memeriksakan kehamilannya, sehingga perlu dilakukan penelitian pengaruh karakteristik ibu dan dukungan suami terhadap pemeriksaan kehamilan di wilayah kerja Puskemas Pargarutan tahun 2012.

\section{TUJUAN PENELITIAN}

Untuk menganalisis pengaruh karakteristik ibu (paritas, usia, pekerjaan, pendidikan) dan dukungan suami (informasional, penilaian, instrumental, emosional) terhadap pemeriksaan kehamilan di wilayah kerja Puskesmas Pargarutan tahun 2012.

\section{METODE PENELITIAN}

Penelitian ini menggunakan metode kuantitatif, jenis penelitian survey dengan pendekatan cross sectional merupakan penelitian dimana pengukuran atau pengamatan dilakukan pada saat bersamaan pada data variabel independen dan dependen (sekali waktu).

\section{POPULASI DAN SAMPEL}

Populasi dalam penelitian ini adalah seluruh ibu hamil yang ada di wilayah kerja Puskesmas Pargarutan Kabupaten Tapanuli Selatan dan memiliki buku KIA berjumlah 139 orang. dengan besar sampel diambil menggunakan rumus yang dikemukakan Slovin dalam Soleh (2005).Jumlah sampel dalam penelitian adalah 74 responden karena peneliti melakukan pembulatan keatas, hal ini disebabkan ada beberapa desa di Kecamatan Angkola Timur yang hanya terdapat $1 \mathrm{ibu}$ hamil yang bila dihitung dengan rumus proporsi mendapatkan hasil 0,46. Bila dilakukan pembulatan kebawah maka desa yang hanya mempunyai jumlah ibu hamil 1 orang tidak termasuk menjadi responden.

\section{HASIL DAN PEMBAHASAN}

\section{Pengaruh Paritas terhadap Pemeriksaan Kehamilan}

Paritas dalam penelitian ini dikategorikan menjadi dua kategori, yaitu paritas berisiko bila ibu mempunyai paritas $>3$ dan kategori tidak berisiko bila paritas ibu $\leq 3$. Dari hasil penelitian didapatkan ibu dengan paritas yang tidak berisiko lebih banyak yang melakukan pemeriksaan kehamilan sesuai standar 52,2\% bila dibandingkan ibu dengan paritas yang berisiko. Berdasarkan hasil analisis regresi logistik menunjukkan bahwa paritas ibu mempunyai pengaruh yang signifikan terhadap kesesuaian pemeriksaan kehamilan dengan nilai $p$ value 0,013 .

Paritas ibu memengaruhi kesesuaian pemeriksaan kehamilan di Kecamatan Angkola Timur disebabkan karena sebagian besar masyarakat telah mengenal program keluarga berencana, ini dibuktikan dengan data keluarga berencana yang tinggi. Dengan masyarakat telah mengenal program keluarga berencana membuat ibu yang mempunyai paritas >3 enggan untuk memeriksakan kehamilan. Keengganan ini disebabkan mereka merasa malu bila mempunyai anak lebih dari tiga. Selain itu ibu hamil dengan paritas berisiko yang tidak melakukan pemeriksaan kehamilan sesuai dengan standar dikarenakan ibu tersebut merasa yakin bahwa kehamilannya baik-baik saja berdasarkan pengalaman kehamilan yang terdahulu.

Hasil penelitian ini sesuai dengan penelitian Maulina (2010), penelitian tersebut mendapatkan hasil bahwa terdapat hubungan antara paritas dengan kunjungan antenatal care. Selanjutnya diperkuat oleh penelitian Swenson et al., (1993) dalam penelitiannya mendapatkan hasil wanita dengan paritas tinggi cenderung kurang memanfaatkan perawatan kehamilan, ibu paritas tinggi lebih percaya diri tentang kehamilannya dan merasa kurang perlu untuk melakukan perawatan kehamilan. Overbosch et al, (2004) bahwa paritas lebih tinggi pada umumnya merupakan penghalang untuk menggunakan pelayanan ANC. 
Dengan melakukan pemeriksaan kehamilan dapat diketahui perkembangan janin dalam kandungan dan dapat dideteksi secara dini bila terdapat kelainan. Pemeriksaan kehamilan diperlukan walau pada umumnya kehamilan berkembang dengan normal dan bayi yang dilahirkan sehat. Selama ini upaya yang telah dilakukan oleh petugas kesehatan khususnya bidan di wilayah Puskesmas Pargarutan hanya melakukan penyuluhan pada saat posyandu.

Dengan hanya melakukan penyuluhan di posyandu dapat dipastikan hanya ibu yang datang ke posyandu yang mendapatkan informasi tersebut. Sementara ibu yang tidak hadir ke posyandu tidak mendapatkan informasi yaitu ibu hamil dengan paritas berisiko karena malu untuk datang ke posyandu.

\subsubsection{Pengaruh Usia terhadap Pemeriksaan Kehamilan \\ Hasil penelitian secara statistik dengan} menggunakan uji regresi logistik berganda menunjukkan bahwa tidak ada pengaruh antara usia ibu dengan pemeriksaan kehamilan dengan nilai $p$ value $0,070(<0,05)$. Ibu hamil yang mempunyai usia tidak berisiko cenderung memeriksakan kehamilan sesuai dengan standar dibandingkan ibu yang mempunyai usia berisiko. Pada penelitian ini usia ibu digolongkan menjadi dua yaitu usia ibu 20-35 tahun digolongkan usia tidak berisiko dan usia kurang dari 20 tahun dan lebih dari 35 digolongkan usia berisiko.

Di Kecamatan Angkola Timur didapati ibu yang mempunyai usia berisiko (usia $<20$ dan usia $>35$ tahun) tidak memeriksakan kehamilan sesuai standar sebanyak 25\%. Meskipun hanya sebagian kecil ibu yang tidak melakukan pemeriksaan kehamilan sesuai standar, hal tersebut tidak boleh diabaikan karena sangat besar manfaat pemeriksaan kehamilan terhadap keselamatan jiwa ibu dan janin. Harus dilakukan upaya-upaya agar ibu hamil melakukan pemeriksaan kehamilan. Ibu yang berusia $<20$ tahun tidak melakukan pemeriksaan kehamilan disebabkan karena merasa terlalu muda untuk hamil dibandingkan teman sebaya mereka. Ibu hamil yang berusia $<20$ tahun yang berada di Kecamatan Angkola Timur jarang keluar rumah. Ibu yang berusia $>35$ tahun tidak melakukan pemeriksaan kehamilan disebabkan mereka merasa malu untuk memeriksakan kehamilan, hal tersebut dapat dilihat pada saat ibu memeriksakan kehamilan selalu menggunakan kain untuk menutup bagian depan tubuh ibu. Mereka menganggap bahwa usia diatas 35 tahun tidak pantas lagi untuk hamil, apalagi bila diikuti dengan jumlah anak lebih dari 3 orang, semakin membuat mereka tidak memeriksakan kehamilan. Dari beberapa orang ibu juga mengatakan mereka merasa kehamilan merupakan hal yang alamiah sehingga tidak perlu periksa hamil. Hal yang diungkap ibu di daerah penelitian hampir sama dengan pernyataan Mathole et al (2004), yang mengatakan bahwa perempuan yang berusia $<35$ tahun lebih sering melakukan kunjungan ke klinik untuk meyakinkan bahwa bayi mereka tumbuh, sedangkan wanita yang lebih tua tidak pernah mengalami masalah, tidak peduli dan menganggap kehamilan merupakan hal biasa.

Penelitian ini tidak sesuai dengan penelitian Ciceklioglu et al., (2005) yang menyatakan ada hubungan yang signifikan antara usia dengan pemeriksaan kehamilan. Matthews et al (2001), berpendapat bahwa mayoritas perempuan dalam usia tiga puluhan melakukan pemeriksaan kehamilan awal dan lebih sering daripada remaja dan wanita yang lebih tua.

Upaya petugas kesehatan di wilayah Puskesmas Pargarutan khususnya bidan yang bertugas di desa selama ini adalah mendatangi rumah ibu hamil untuk melakukan pemeriksaan kehamilan. Bagi bidan yang tinggal di desa dan mengikuti segala aktifitas kehidupan di desa binaan, bidan dapat mengetahui dengan pasti ibu-ibu yang hamil. Namun bila bidan yang bertugas di desa tidak tinggal didesa dikarenakan berbagai alasan, hal itu akan terlewatkan.

\subsubsection{Pengaruh Pendidikan terhadap Pemeriksaan Kehamilan \\ WHO dalam Deswani (2003), menyatakan} bahwa wanita yang berpendidikan lebih tinggi cenderung lebih memperhatikan masalah kesehatan baik untuk dirinya sendiri maupun keluarganya. Sehingga akan lebih mudah memanfaatkan pelayanan antenatal. Pendidikan memengaruhi cara berpikir, tindakan dan pengambilan keputusan yang akan dilakukan seseorang untuk memanfaatkan dan menggunakan pelayanan kesehatan. Tingkat pendidikan juga memengaruhi kemampuan seseorang untuk mendengar, menyerap informasi dan dalam mengambil keputusan. Dalam hal ini termasuk mendengarkan, menyerap informasi dan dalam mengambil keputusan untuk melakukan pemeriksaan kehamilan.

Berdasarkan uji regresi logistik didapatkan hasil p value 0,143 $(<0,05)$, yang secara statistik menunjukkan bahwa tidak terdapat pengaruh antara pendidikan ibu terhadap kesesuaian pemeriksaan kehamilan. Dalam penelitian ini penelitian responden dikategorikan menjadi dua kategori yaitu responden yang menamatkan SD sederajat dan SLTP sederajat dikategorikan pendidikan dasar, dan bila responden menamatkan SLTA sederajat dan Perguruan Tinggi dikategorikan pendidikan tinggi

Ada beberapa penelitian yang menguatkan penelitian ini diantaranya adalah penelitian yang dilakukan oleh Kristina (2000), yaitu tidak ada hubungan pendidikan ibu terhadap kunjungan ulang antenatal care yang dilakukan ibu. Demikian pula hasil penelitian yang dilakukan oleh Maulina (2010), bahwa tidak ada hubungan yang signifikan antara pendidikan ibu dengan kelengkapan kunjungan antenatal yang dilakukan ibu.

Sebagian besar ibu hamil yang menjadi responden dalam penelitian ini berpendidikan terakhir SLTA, yang bila dihubungkan dengan variabel pekerjaan sebagian besar responden bekerja sebagai petani. Selain tidak mempunyai kesempatan untuk melakukan pemeriksaan kehamilan para responden juga kurang mengetahui manfaat periksa hamil. Hal itu disebabkan karena responden kurang mendapatkan informasi tentang 
pentingnya periksa hamil, karena sebagian waktu dihabiskan disawah.

Pendidikan responden yang tinggi tidak menjamin kesesuaian pemeriksaan kehamilan, hal ini disebabkan pendidikan yang dilalui oleh responden adalah pendidikan formal. Meskipun pendidikan tinggi membuat seseorang mudah menyerap informasi dan dalam mengambil keputusan, namun bila informasi tidak didapat maka seseorang tidak dapat mengambil keputusan. Dalam pendidikan formal responden tidak mendapatkan informasi tentang pentingnya pemeriksaan kehamilan. Hal ini merupakan salah satu yang membuat responden tidak mengetahui pentingnya manfaat pemeriksaan kehamilan sehingga tidak melakukan pemeriksaan kehamilan.

\subsubsection{Pengaruh Pekerjaan terhadap Pemeriksaan Kehamilan}

Berdasarkan analisis bivariat yang telah dilakukan menunjukkan bahwa hipotesis ditolak dengan nilai $p$ value $0,367(>0,05)$ yang berarti tidak ada pengaruh antara pekerjaan terhadap pemeriksaan kehamilan. Untuk selanjutnya variabel pekerjaan tidak dimasukkan lagi dalam model selanjutnya.

Hasil penelitian ini berbeda dari hasil penelitian yang dilakukan sebelumnya oleh Sjofiatun (2000), pada penelitian Sjofiatun menyebutkan bahwa status ibu bekerja mempunyai pengaruh yang signifikan terhadap perawatan kehamilan di daerah pedesaan maupun didaerah perkotaan. Selanjutnya penelitian yang dilakukan oleh Kabir et al. (2005), perempuan yang bekerja lebih memanfatkan pelayanan antenatal care dibandingkan ibu rumah tangga dan ibu yang tidak bekerja. Selanjutnya wanita yang bekerja cenderung memulai antenatal care lebih awal (Magadi et al., 2002). Wanita yang bekerja di luar rumah selama kehamilan secara signifikan berhubungan terhadap pelayanan pemeriksaan kehamilan (Erci, 2003).

Ibu yang bekerja disektor formal memiliki akses yang lebih baik terhadap informasi kesehatan, informasi tersebut didapatkan dari teman di tempat bekerja maupun dari media seperti dari Koran, majalah, internet dan lain-lain. Selain itu ibu yang bekerja secara formal akan mempunyai penghasilan sendiri dan menambah penghasilan keluarga sehingga dari segi ekonomi akan mapan dan mampu menggunakan fasilitas kesehatan dan memanfaatkan fasilitas kesehatan dengan baik.

Di Kecamatan Angkola Timur sebagian besar ibu yang bekerja di sektor informal yaitu sebagai petani. Petani bekerja di sawah dari pagi sampai sore hari, hal inilah salah satu penyebab ibu melakukan pemeriksaan kehamilan tidak sesuai dengan standar. Selain ibu menghabiskan waktu di sawah, pulang dari sawah ibu harus mengurus keluarga sehingga dapat dipastikan ibu tidak mempunyai kesempatan untuk periksa hamil. Selain itu juga tidak mendapatkan informasi tentang pentingnya periksa hamil baik dari petugas kesehatan maupun dari media lain. Sehingga ibu tidak tahu dan tidak punya waktu untuk memeriksakan kehamilannya. Ibu melakukan pemeriksaan kehamilan bila tidak ke sawah dan mempunyai waktu, sebab selain ke sawah ibu juga mempunyai kegiatan lain seperti menganyam tikar untuk menambah penghasilan.

\subsection{Pengaruh Dukungan Terhadap Pemeriksaan Kehamilan}

\subsubsection{Pengaruh Dukungan Informasional terhadap Pemeriksaan Kehamilan}

Berdasarkan hasil analisis uji statistik menunjukkan dukungan informasional yang diberikan oleh suami tidak mempunyai pengaruh yang signifikan terhadap kesesuaian pemeriksaan kehamilan, dengan nilai $p=0,234$ $(>0,05)$. Hasil penelitian ini menguatkan hasil penelitian sebelumnya yang dilakukan Maulina (2010), yang menyatakan bahwa tidak ada hubungan antara dukungan keluarga dengan kelengkapan pemeriksaan kehamilan.

Dukungan informasional adalah dukungan yang diberikan suami berupa pemberian informasi tentang pentingnya pemeriksaan kehamilan (termasuk tablet fe, imunisasi TT, buku KIA), jumlah pemeriksaan, dan tempat pemeriksaan kehamilan. Secara statistik dukungan informasional dari suami tidak berpengaruh terhadap kesesuaian pemeriksaan kehamilan yang dilakukan oleh ibu. Dari tabulasi silang didapatkan hasil bahwa ibu yang tidak mendapatkan dukungan informasional hanya sedikit sekali perbedaannya antara yang tidak mendapat dukungan melakukan pemeriksaan kehamilan yang sesuai (43,8\%), dengan yang tidak mendapat dukungan dan memeriksakan kehamilan yang tidak sesuai (56,3\%).

Dari hasil penelitian yang dilakukan hanya 35,1\% suami memberi informasi bahwa ibu harus periksa hamil, hal ini membuat ibu tidak memeriksakan kehamilannya. Informasi yang kurang diberikan oleh suami mungkin saja karena suami sendiri kurang memahami tentang manfaat, kerugian pemeriksaan kehamilan. Karena suami tidak mengetahui tentang penting pemeriksaan kehamilan maka suami tidak mencari tahu, sehingga suami tidak dapat memberikan informasi kepada ibu. Kurangnya pengetahuan suami tentang pemeriksaan kehamilan dapat juga disebabkan oleh faktor budaya yang menganggap bahwa urusan kehamilan, melahirkan merupakan urusan perempuan sehingga suami tidak perlu mencari informasi tentang pemeriksaan kehamilan.

Selain faktor budaya kurangnya pengetahuan suami disebabkan karena selama ini petugas kesehatan dalam memberikan penyuluhan tentang kehamilan hanya para ibu yang dijadikan sasaran tanpa melibatkan suami. Penyuluhan hanya dilakukan saat posyandu, sehingga dapat dipastikan yang mendengarkan penyuluhan itu hanya para ibu.

\subsubsection{Pengaruh Dukungan Penilaian/ penghargaan terhadap Pemeriksaan Kehamilan}

Hasil uji statistik dengan menggunakan regresi logistik berganda didapatkan nilai $p$ value 0,490 ( $>0,05)$, hal tersebut menunjukkan bahwa variabel dukungan penilaian/ penghargaan tidak berpengaruh terhadap pemeriksaan kehamilan.

Dukungan penilaian/ penghargaan dalam penelitian ini adalah upaya dari suami untuk 
memberikan umpan balik berupa pujian, bimbingan dan perhatian kepada ibu dalam melakukan pemeriksaan kehamilan. Dalam penelitian didapatkan hasil bahwa hanya $43,2 \%$ ibu yang mendapat pujian dari suami bila pulang memeriksakan kehamilan. Hal tersebut dapat saja membuat ibu merasa enggan untuk melakukan pemeriksaan kehamilan selanjutnya.

Para suami yang berada ditempat penelitian bahkan wilayah Tapanuli Selatan khususnya mempunyai sifat tertutup. Sehingga tidak dapat mengungkapkan perasaannya secara terbuka. Ada perasan malu untuk memuji istri bila tindakan istri benar. Asumsi peneliti hal ini yang menyebabkan suami kurang memberikan dukungan penilaian/ penghargaan.

Hasil temuan ini sesuai dengan penelitian yang dilakukan Deswani (2003), yang menyatakan bahwa tidak ada hubungan dukungan sosial dengan kunjungan antenatal yang dilakukan ibu.

\subsubsection{Pengaruh Dukungan Instrumental terhadap Pemeriksaan Kehamilan}

Hasil analisa statistik uji regresi logistik berganda menunjukkan bahwa variabel dukungan instrumental pada $\alpha$ 5\% berpengaruh terhadap pemeriksaan kehamilan, dengan nilai $p$ value $0,017(\mathrm{p}<0,05)$. Ibu hamil yang mendapatkan dukungan instrumental dari suami cenderung melakukan pemeriksaan kehamilan sesuai standar dibandingkan ibu yang tidak mendapat dukungan dari suami.

Dukungan instrumental menurut Cohen et al., (1985), menunjukkan ketersediaan sarana untuk memudahkan perilaku menolong orang yang menghadapi masalah berbentuk materi, pemberian kesempatan dan peluang waktu.

Dukungan instrumental dalam penelitian ini berupa upaya dari suami untuk memberikan bantuan dalam bentuk dana, waktu dan memfasilitasi ibu untuk melakukan pemeriksaan kehamilan. Sehingga dengan didapatkannya dukungan instrumental dari suami, istri melakukan pemeriksaan kehamilan sesuai dengan standar yang ada. Hampir sebagian besar masyarakat di Indonesia demikian, suami adalah pengambil keputusan utama. Oleh karena itu dukungan dari suami akan sangat besar dampaknya terhadap keputusan ibu untuk memeriksakan kehamilan.

Faktor budaya yang menganggap bahwa kehamilan, persalinan merupakan urusan perempuan juga merupakan penyebab suami kurang memberikan dukungan instrumental kepada ibu untuk melakukan pemeriksaan kehamilan. Hal tersebut berdasarkan hasil penelusuran jawaban responden bahwa 33,8\% saja suami yang mengantarkan ibu memeriksakan kehamilan, berdasarkan jawaban tersebut seakan-akan suami tidak peduli terhadap kehamilan istri. Namun sebenarnya suami sangat antusias menanggapi kehamilan ibu, hal ini dibuktikan berdasarkan jawaban responden bahwa sebagian besar 60,8\% suami menyediakan transportasi, membantu pekerjaan rumah agar ibu dapat memeriksakan kehamilan 56,8\% dan mau meninggalkan pekerjaan untuk mengantarkan ibu periksa hamil $62,2 \%$.

Dukungan intrumental dari suami terhadap pemeriksaan kehamilan di Kecamatan Angkola Timur lebih pada dukungan yang tidak dilihat oleh orang lain hanya ibu yang merasakan dukungan tersebut, berdasarkan jawaban responden hanya 33,8\% yang mengantarkan ibu periksa hamil. Sebenarnya dengan hanya mengantarkan ibu untuk periksa hamil secara tidak langsung indikator dukungan instrumental yang lain sudah dilakukan oleh suami, seperti menyediakan transportasi, mendampingi masuk ke ruang periksa, meninggalkan pekerjaan untuk mengantarkan ibu. Namun belum semua suami melakukan karena faktor budaya tersebut.

Peran tokoh agama sangat dibutuhkan dalam hal ini mengingat masyarakat Tapanuli Selatan sangat menghormati tokoh agama. Selain itu meningkatkan dukungan suami dapat dilakukan dengan meningkatkan konseling petugas kepada suami pada saat ibu memeriksakan kehamilan. Selama ini jarang dilakukan karena ibu hamil sering datang sendiri untuk periksa hamil tanpa ditemani suami. Sehingga informasi penting bagi suami tidak didengarkan langsung oleh suami.

Penelitian ini sesuai dengan penelitian Simkhada et al., (2008), wanita yang mendapatkan dukungan dari orang-orang terdekat selama kehamilan dua kali lebih mungkin untuk hadir dalam melakukan pemeriksaan kehamilan dibandingkan dengan wanita yang tidak mendapatkan dukungan. Demikian pula penelitian Simanjuntak (2002), menyatakan bahwa ada hubungan yang bermakna antara dukungan suami terhadap kunjungan antenatal yang sesuai.

\subsubsection{Pengaruh Dukungan Emosional terhadap Pemeriksaan Kehamilan \\ Hasil uji statistik menunjukkan ada pengaruh} antara dukungan emosional yang diterima ibu dengan pemeriksaan kehamilan, dengan nilai $p$ value 0,007 ( $p$ $<0,05$ ). Ibu hamil yang mendapatkan dukungan emosional lebih cenderung memeriksakan kehamilan sesuai standar dibandingkan ibu yang tidak mendapatkan dukungan emosional. Nilai exp (B) 9,335 yang berarti bahwa ibu yang mendapatkan dukungan emosional dari suami mempunyai kemungkinan 9,3 kali untuk melakukan pemeriksaan kehamilan sesuai standar dibandingkan ibu yang tidak mendapatkan dukungan emosional dari suami.

Dukungan emosional suami dalam penelitian ini adalah adanya upaya dari suami untuk membantu kenyamanan dan ketenangan emosi, mencakup mendengarkan keluhan, empati, menunjukkan kasih sayang dan motivasi kepada ibu dalam melakukan pemeriksaan kehamilan.

Penelitian Carter 2002 dalam Kurniarum (2006), yang menyatakan bahwa dukungan suami memberikan kontribusi penting bagi kesehatan. Dukungan sosial yang dibutuhkan adalah berupa dukungan emosional yang mendasari tindakan. Dengan dukungan tersebut ibu akan merasa diperhatikan, dicintai, dimuliakan dan dihargai. Adanya kehadiran orang terdekat dapat mempengaruhi 
emosional atau efek perilaku bagi penerimanya. Dukungan selama kehamilan berpengaruh terhadap hasil kehamilan.

Menurut Henderson (2005), ada beberapa faktor yang berperan dalam meningkatkan kemampuan wanita dalam beradaptasi terhadap kehamilan, misalnya lingkungan sosial, dukungan sosial dan dukungan dari pemberi asuhan. Dukungan yang diberikan oleh suami dan keluarga dapat memengaruhi persepsi terhadap kehamilan dan memengaruhi tingkat kecemasan yang ibu alami.

Dukungan suami adalah bentuk dukungan dan hubungan baik merupakan kontribusi yang penting bagi kesehatan. Dukungan emosional yang mendasari pemberian dukungan sosial. Adanya kehadiran orang terdekat dapat memengaruhi emosional atau efek perilaku bagi penerimanya (Larson, 2004).

Seorang wanita pada saat hamil terjadi perubahan berupa peningkatan hormonal yang memengaruhi sistem tubuh baik fisik maupun psikologi. Perubahan psikologi yang terjadi sering membuat ibu merasa sedih, cemas dan apabila tidak mendapat dukungan dari orang sekitar ibu merasa tidak dihargai dan disayangi. Dukungan emosional membuat ibu merasa lebih dihargai, nyaman, aman dan disayangi. Hal ini dapat pula dipengaruhi oleh budaya. Budaya masyarakat Tapanuli Selatan yang menganut budaya Islam bahwa yang memegang peranan penting dalam rumah tangga adalah suami. Para ibu akan melakukan pemeriksaan kehamilan apabila ibu mendapat dukungan dari suami.

Hasil penelitian sesuai dengan penelitian Erci (2003), Dukungan sosial yang diterima dari keluarga meningkatkan jumlah kunjungan dan ibu hamil melakukan kunjungan lebih awal. Sosial support berpengaruh secara signifikan terhadap jumlah kunjungan antenatal care. Dukungan sosial yang tidak memadai merupakan hambatan untuk memperoleh pelayanan kehamilan.

\section{KESIMPULAN}

1. Karakteristik ibu yang berpengaruh terhadap pemeriksaan kehamilan adalah paritas ibu, sedangkan yang tidak berpengaruh terhadap pemeriksaan kehamilan adalah usia, pendidikan dan pekerjaan ibu.

2. Dukungan suami yang berpengaruh terhadap pemeriksaan kehamilan adalah dukungan instrumental dan dukungan emosional, sedangkan yang tidak berpengaruh terhadap pemeriksaan kehamilan adalah dukungan informasional dan dukungan penilaian/ penghargaan.

3. Variabel yang paling dominan adalah dukungan emosional yang berpengaruh terhadap pemeriksaan kehamilan.

\section{SARAN}

Berdasarkan kesimpulan, maka dapat diberikan saran atau rekomendasi sebagai berikut:

1. Kepada Dinas Kesehatan Tapanuli Selatan perlu bekerjasama dengan tokoh agama dalam meningkatkan peran serta suami dalam pemeriksaan kehamilan

2. Kepada Puskesmas perlu melakukan peningkatan sosialisasi dan penyuluhan rutin tentang pemeriksaan kehamilan dengan mengikut sertakan para suami, agar suami paham bahwa dukungan suami mempunyai andil dalam peningkatan cakupan pemeriksaan kehamilan.

3. Penelitian ini hanya melihat dukungan suami dari persepsi ibu, perlu penelitian lanjutan tentang partisipasi suami sehingga dapat benar-benar diketahui hal yang paling berpengaruh terhadap kunjungan pemeriksaan kehamilan agar dapat memberi kontribusi terhadap riset ilmiah di masa akan datang.

\section{DAFTAR PUSTAKA}

Admin.(2008). Peran Suami Dalam Persiapan Persalinan Aman. http/www. Departemen Kesehatan, Indonesia.htm (dikutip tanggal 17 Jan 2010).

Andersen R.M., (1995), Revisiting The Behavior Model and Acces to Medical care. Journal of Health and Social Behavior.

Beni, R., (2000). Keterlibatan Suami pada Masa Kehamilan : Menuju Kesetaraan Gender dalam proses Reproduksi Sehat. Warta Demografi Vol 30 no 04 2006 (http://lib.atmadjaya.ac.id)

BKKBN. (2004). Diskriminasi Kerja Perempuan, Kekerasan Terhadap Perempuan. http;//www bkkbn.go.id

-----------. (2007). Bahan Pembelajaran Peningkatan Partisipasi Pria dalam KB dan Kesehatan Reproduksi. BKKBN.Jakarta.

Bobak, Lowdermilk \& Jensen, (2004), Buku Ajar Keperawatan Maternitas (Terjemahan Edisi 4), EGC, Jakarta.

Caplin, J.P., (2006), Kamus Lengkap Psikologi Alih Bahasa Kartini Kartono, Raja Grafindo Persada, Jakarta.

Catherine A Haney., Barbara A Israel. (2008). Health Behavior and Health Education: Theory, Research and Practice. Publisher Josseybass.

Ciceklioglu M., Soyer M.T., Ocek Z.A. (2003). Factor Associated With The Utilization and Content of Prenatal Care In a Western Urban Distric of Turkey. International Journal Of Quality In Health Care.

Cui. Y., Yang. L., Lü. MT., Analysis On The Status of Antenatal Checkup Program In Certain Areas of China, (2005), Zhonghua Liu Xing Bing Xue Za Zhi. 2009 http://www.ncbi.nlm.nih.gov/pubmed/.

Sep;30(9):887-90,

Cuningham, DKK, (2005), Williams Obstetrics 21 st Edition, Medical Publishing.

Cohen, S. \& Syme, S.L . ed (1985) Social Support and Health. Orlando Florida: Academic Press Inc.

Depdikbud. (2003). Kamus Besar Bahasa Indonesia Balai Pustaka. Jakarta. 
Depkes RI, (2001), Yang Perlu Diketahui Petugas Kesehatan Tentang Kesehatan Reproduksi. Depkes RI. Jakarta.

Deswani, (2003), Hubungan Faktor Determinan pada Ibu Hamil dengan Kedatangan pada Kunjungan kepelayanan Antenatal dalam Keperawatan Maternitas dalam Konteks Keluarga Di Kelurahan Cipinang Besar Utara Jakarta Timur, Thesis, Universitas Indonesia, Jakarta.

Dinkes Sumut , (2007), Pedoman Pemantauan Wilayah setempat Kesehatan Ibu dan Anak.

Erci B. (2003). Barrier To Utilization of Prenatal care Service In Turkey, Journal In Nursing Scholarship.

Glanz, K., Rimer, B K., Viswanath, K., (2008), Health Behavior and Health Education Theory, Research and Practice, Josseybass Publishing

Gottlieb, B.H. (1983) Social Support Strategies, Guidelines for Mental Health Prcatice. London. Sage Publication Beverly Hills.

Henderson. C., (2005), Konsep Kebidanan, EGC, Jakarta.

Hamid, Z.M, (2003), Hubungan pengetahuan dan Sikap Ibu dengan Pemeriksaan Kehamilan di Kabupaten Serang Provinsi Banten, Thesis, Universitas Indonesia, Jakarta.

Kabir M., Iliyasu Z., Abu Bakar I.S \& Sani A.A., (2005), Determinant of Utilization of Antenatal Care Service in Kumbotso Village, Northern Nigeria. Tropical Doctor.

Kemalahayati. (2008). Dukungan Suami Terhadap Kesiapan Ibu Primigravida Menghadapi Persalinan di Daerah Pedesaan Langsa Nanggroe Aceh Darussalam, Thesis, Universitas Indonesia, Jakarta.

Kementrian Kesehatan Republik Indonesia. (2010). Profil Kesehatan Indonesia, Jakarta.

Kristina A. (2005) Hubungan Beberapa Karakteristik Ibu Dan Persepsi Ibu Terhadap Kualitas Pelayanan Dengan Kunjungan Ulang Antenatal di Wilayah Kerja Puskesmas Padangsari Kota Semarang. Thesis, Universitas Diponegoro. Semarang.

Kurniarum A, (2006), Hubungan Dukungan Suami dengan Depressive Symptoms Pada Ibu Hamil dalam Ruang Lingkup Pedesaan dan Perkotaan, Thesis, UGM, Jogjakarta.

Larson, C., Sydsjo, G. \& Josefsson. (2004) Health, Sociodemografi Data, and Pregnancy Outcome in Women With Antepartum Depressive Symptoms, Journal Obstetrics \& Gynecology, 104:459-466.

Lucyanawaty, M. (2008). Keselamatan ibu (Safe Motherhood) dan perkembangan anak: Bagaimana peran laki-laki? http :// situs.kesrepro. info/gendervaw02.htm (dikutip tanggal 10 Juli 2009).

Magadi M.A., Madise N.J. \& Rodrigues R.N., (2000). Frequency and Timing of Antenatal Care in Kenya; Explaining the Variations Between Women of Different Communities. Social Science \& Medicine.

Mansur, H., (2009), Psikologi Ibu dan Anak untuk Kebidanan, Salemba Medika, Jakarta.

Manuaba, IBG.(1998). Ilmu Kebidanan. Penyakit Kandungan dan Keluarga Berencana Untuk Pendidikan Bidan. EGC. Jakarta.
Mathole T., Lindmark G., Majoko F., Ahlberg B.M., (2004). A Qualitative Study of Woman Perspectives of Antenatal Care In a Rural Area of Zimbabwe. Midwifery.

Matthew Z., Mahendra S., Kilaru A., \& Ganapathy S., (2001). Antenatal Care, Care Seeking and Morbidity In Rural Karnataka India. Asia-Pasific Population Jurnal

Maulina C.H, (2010), Analisis Faktor yang Berhubungan dengan Kelengkapan Pemeriksaan Kehamilan pada Ibu yang Memiliki Balita di Kelurahan Tanjung Rejo Kecamatan Medan Sunggal, Skripsi, Universitas Sumatera Utera. Medan.

Muchtar, A. (2004). Memaknai Hari Ibu dengan Menghormati Hak Reproduksinya. http :// situs.kesrepro. info/gendervaw02.htm (dikutip tanggal 10 Des 2010).

Muslihatun W.N., Mufdillah, Setiyawati N, (2009), Dokumentasi Kebidanan, fitramaya, Jogjakarta.

Nielsen B.B., Hedegaard M., Liljestrand J., Thilsted S.H. \& Joseph A., (2001). Characteristic of Antenatal Care Attenders In a Rural Population In Tamil Nadu, South India, Health and Social Care in The Community. http://www.ncbi.nlm.nih.gov/pubmed/

Notoadmodjo, S., (2003). Pendidikan dan Prilaku Kesehatan Masyarakat. PT Rineka Citta. Jakarta.

------------, (2002). Metodologi Penelitian Kesehatan. Rineka Cipta. Jakarta.

Overbosch G., Nsowah-Nuamah N., Van den Boom G \& Damnyang L., (2004). Determinant of antenatal Care Use In Ghana. Journal of African Economies

Prawiroharjdo., (2002). Pelayanan Kesehatan Maternal dan Neonatal YBP-SP. Jakarta.

Prianggoro. H.(2008), Ternyata Peran Suami Saat Istri Hamil Sangat Penting Karena Bisa mempengaruhi Kehamilan Termasuk Janin. http// situs.kesrepro. info/gendervaw02.htm (dikutip tanggal 2 Maret 2011)

Puspa. (2009). Fungsional Pengantar Kerja, http;//www. Infokerja-jatim

Roeshadi R.H., (2006), Upaya Menurunkan Angka Kesakitan dan Angka Kematian Ibu pada Preeklamsi dan Eklamsi. http://Repositori.usu.ac.id diakses tanggal $23 / 4 / 2011$

Saifuddin, A, B., (2001). Buku Acuan Pelayanan Kesehatan Maternal Neonatal, Yayasan Bina Pustaka Sarwona Prawirohardjo, Jakarta.

---------(2002). Buku Panduan Praktis Pelayanan Kesehatan Maternal Neonatal, Yayasan Bina Pustaka Sarwono Prawirohardjo, Jakarta.

Salmah, Rusmiati, Maryanah, Susanti N.N., (2007), Asuhan Kebidanan Antenatal, EGC, Jakarta

Sarason. I.G., Sarason B (1997). Interrelation of Social Support Measures; Theoritical and Practical Implication. Journal of Personality and Social Psychology.

Simanjuntak T., (2002), Faktor-Faktor yang Berhubungan dengan Kunjungan Antenatal K4 di Kota Medan Provinsi Sumatera Utara, Thesis, Universitas Indonesia, Jakarta. 
Simkhada B, Teijlingen ER, Porter M, Simkhada P., (2007), Factors Affecting The Utilization of Antenatal Care in Developing Countries: Systematic Review of The Literature, J Adv Nurs. 2008 Feb; 61(3) :244-60, http://www.ncbi.nlm.nih.gov/pubmed/

Sjofiatun, N. (2000). Pengaruh Karakteristik Wanita dan Rumah Tangga Terhadap Pemanfaatan Pelayanan Kesehatan Ibu di Indonesia (Analisis Data SDKI 1997). Thesis. Universitas Indonesia, Jakarta.

Soleh. (2005). Ilmu Statistika: Pendekatan Teoritis dan Aplikatif disertai contoh Penggunaan SPSS, Jakarta: Rekayasa Sains.o

Sudarsono. (2008). Karakter Is Striving System Which Underly Behavior, http;/www.pelita.or.id

Swasono M F.,(1998), Kehamilan, Kelahiran, Perawatan Ibu dan Bayi dalam Kontek Budaya, UI Press, Jakarta.

Swenson IE, Thang NM, VQ Nhan, PX Tieu. (1993). Faktor Related To The Utilization of Prenatal care In Vietnam. Journal Trop Med Hyg 1993 Apr;96(2):7685. http://www.ncbi.nlm.nih.gov/pubmed/

Teddy KW., (2008). Faktor-Faktor yang Mempengaruhi Prilaku; hthp// www. World press.com. dikutip tanggal 4 Desember 2010
Thaddeus.S dan Maine.D., (1994), Top Far fo Walk: Maternal Mortality in Context.

Tombukan, S., (2003). Hubungan Pengetahuan dengan Sikap ibu Hamil Tentang Tanda Bahaya Kehamilan di PKM Jetis Tahun 2002. FK. UGM Yogyakarta.

Wikjosastro. H, Saifuddin A.B, Rachimhadi.T, (1997), Ilmu Kebidanan, Yayasan Bina Pustaka Sarwono Prawirohardjo, Jakarta. , (2002), Ilmu Kebidanan, Yayasan Bina Pustaka Sarwono Prawirohardjo, Jakarta.

Yasril, Kasjono.H.S, Analisis Multivariat Untuk Penelitian Kesehatan, Mitra Cendikia, Jogjakarta.

Yayasan Pendidikan Kesehatan Perempuan, (2006), Kesehatan Reproduksi Modul, Yayasan Pendidikan Kesehatan Perempuan Bekerja sama dengan Pusat Pendidikan Tenaga Kesehatan Departemen Kesehatan dan Ikatan Bidan Indonesia, Jakarta.

Yulianto,WA. (2004). Refleksi Wafatnya RA Kartini bagi Para Suami. www.situs.kesrepro.info/gendervaw/apr/2004/genderva w03.htm (dikutip tanggal 1April 2011).

Yustina I, (2007). Upaya Strategis Menurunkan AKI dan AKB. Jurnal Wawasan Ilmu-Ilmu Sosial, 13 (2) : $182-187$. 